\title{
PENGARUH GAYA KEPEMIMPINAN, MOTIVASI KERJA DAN \\ DISIPLIN KERJA TERHADAP KINERJA PEGAWAI BADAN \\ KEPEGAWAIAN DAN PENGEMBANGAN SUMBER DAYA MANUSIA \\ DAERAH KABUPATEN KERINCI
}

\author{
IMAM ARDIAN, ELFISWANDI, IMAM ARDIAN
}

\section{FAKULTAS EKONOMI DAN BISNIS UNIVERSITAS PUTRA INDONESIA "YPTK" PADANG}

\author{
E-mail : \\ im.ardian50@gmail.com \\ elfiswandi@upiyptk.ac.id
}

\begin{abstract}
This study aims to determine how much p engaruh leadership style, motivation of work, and discipline to employee performance BKPSDMD Kerinci, with a sample of 95 respondents employee BKPSDMD Kerinci district. The analytical method used is multiple regression analysis. The research results obtained based on partial test ( $t$ test) obtained: (a) partially there is a significant influence between leadership style on employee performance. Thus Ho is rejected and $\mathrm{Ha}$ is accepted. (b) partially significant effect between employee motivation t erhadap employee performance. Thus Ho is rejected and Ha is accepted. (c) partially significant effect between work discipline of work t erhadap employee performance. Thus Ho is rejected and Ha is accepted. (d) then based on the results of joint hypothesis testing (Test F) leadership style, work motivation, and work discipline positive and significant effect on employee performance. Based on the test of the coefficient of determination $\left(\mathrm{R}^{2}\right)$ obtained a value of $74.1 \%$, this indicates that the percentage contribution of independent variables of leadership style, employee motivation, and discipline by $74.1 \%$ while the remaining $25.9 \%$ influenced by variables outside the research, such as employee commitment, organizational culture, training, and work environment. Finally, the authors suggest to the Kerinci Regency BKPSDMD to be able to increase work motivation and employee work discipline, leaders can implement a better leadership style and maintain a good leadership style .

Keywords: Leadership Style, Work Motivation, Work Discipline and Employee Performance
\end{abstract}

ABSTRAK
Penelitian ini bertujuan untuk mengetahui seberapa besar pengaruh gaya
kepemimpinan, motivsi kerja, dan disiplin kerja terhadap kinerja pegawai
BKPSDMD Kabupaten Kerinci, dengan sampel 95 responden pegawai BKPSDMD
Kabupaten Kerinci. Metode analisis yang digunakan adalah analisis regresi
berganda. Hasil penelitian yang didapatkan berdasarkan uji parsial (uji t) diperoleh
: (a) secara parsial terdapat pengaruh signifikan antara gaya kepemimpinan
terhadapat kinerja pegawai. Dengan demikian Ho ditolak dan Ha diterima. (b)


secara parsial terdapat pengaruh signifikan antara motivasi kerja terhadap kinerja pegawai. Dengan demikian Ho ditolak dan Ha diterima. (c) secara parsial terdapat pengaruh signifikan antara disiplin kerja kerja terhadap kinerja pegawai. Dengan demikian Ho ditolak dan Ha diterima. (d) kemudian berdasarkan hasil uji hipotesis secara bersama-sama (Uji F) gaya kepemimpinan, motivasi kerja, dan disiplin kerja berpengaruh positif dan signifikan terhadap kinerja pegawai.Berdasarkan uji koefisien determinasi $\left(\mathrm{R}^{2}\right)$ diperoleh nilai sebesar $74,1 \%$ hal ini menunjukkan bahwa persentase sumbangan variabel independen gaya kepemimpinan, motivasi kerja, dan disiplin kerja sebesar $74,1 \%$ sedangkan sisanya sebesar 25,9\% dipengaruhi dari variabel diluar penelitian, seperti komitmen pegawai, budaya organisai, pelatihan, dan lingkungan kerja. Akhirnya penulis menyarankan kepada BKPSDMD Kabupaten kerinci untuk dapat meningkatkan motivasi kerja dan disiplin kerja pegawai, pimpinan dapat menerapkan gaya kepemimpinan yang lebih baik lagi serta mempertahankan gaya kepemimpinan yang telah baik.

Kata kunci : Gaya Kepemimpinan, Motivasi Kerja, Disiplin Keja dan Kinerja Pegawai

\section{PENDAHULUAN}

Organisasi merupakan kesatuan sosial yang yang dikoordinasikan secara sadar, dengan sebuah batasan yang relatif dapat diindentifikasikan, bekerja secara terus menerus untuk mencapai tujuan Robbins \& Judge (2014:256). Akibat terjadinya interaksi dengan karakteristik masing-masing serta banyak kepentingan yang membentuk gaya hidup, pola perilaku, dan etika kerja, yang kesemuanya akan mencirikan kondisi suatu organisasi. Sehingga setiap individu dalam organisasi tidak lepas dari hakekat nilai-nilai budaya yang dianutnya, yang akhirnya akan bersinergi dengan perangkat organisasi, teknologi, sistem, strategi dan gaya hidup. Sehingga pola interaksi sumber daya manusia dalam organisasi harus diseimbangkan dan diselaraskan agar oganisasi dapat tetap eksis.

Sumber daya manusia merupakan tokoh sentral dalam organisasi. Agar aktivitas manajemen berjalan dengan baik, organisasi harus memiliki pegawai yang berpengetahuan dan berketrampilan tinggi serta usaha untuk mengelola organisasi seoptimal mungkin sehingga kinerja pegawai meningkat. Kinerja pegawai adalah hasil kerja secara kualitas dan kuantitas yang dicapai oleh seseorang pegawai dalam melaksanakan tugasnya sesuai dengan tanggung jawab yang diberikan kepadanya Mangkunegara (2017:88). Kinerja yang baik adalah kinerja yang optimal, yaitu kinerja yang sesuai standar organisasi dan mendukung tercapainya tujuan organisasi. Organisasi yang baik adalah organisasi yang berusaha meningkatkan kemampuan sumber daya manusianya, karena hal tersebut merupakan faktor kunci untuk meningkatkan kinerja pegawai.

Badan Kepegawaian dan Pengembangan Sumber Daya Manusia Daerah (BKPSDMD) Kabupaten Kerinci mempunyai tugas pokok membantu kepala daerah dalam menyelenggarakan pemerintahan daerah dibidang manajemen kepegawaian daerah meliputi pengelolaan dan pembinaan kepegawaian daerah sesuai dengan kewenangan yang dimiliki daerah. 
Tujuan Badan Kepegawaian dan Pengembangan Sumber Daya Manusia Daerah (BKPSDMD) Kabupaten Kerinci Secara umum adalah tersusunnya Sistem Manajemen Kepegawaian yang Komprehensif mencakup Aspek Perencanaan, Pengangkatan, Pengembangan, Pemberhentian dan Peningkatan Kompetensi serta Profesionalisme PNS dalam perwujudan pelaksanaan Tata Pemerintahan yang baik (Good Governance) di Kabupaten Kerinci.

Program yang telah ditetapkan Badan Kepegawaian dan Pengembangan Sumber Daya Manusia Daerah (BKPSDMD) Kabupaten Kerinci adalah : 1) Ketatausahaan. 2) Pengembangan Karir Pegawai Negeri Sipil. 3) Peningkatan SDM Pegawai Negeri Sipil. 4) Pembinaan dan Peningkatan Disiplin Pegawai Negeri Sipil. 5) Mutasi dan Promosi Pegawai Negeri Sipil. 6) Kenaikan Pangkat dan Pensiun Pegawai Negeri Sipil. 7) Pengembangan SIMPEG. 8) Peningkatan insentif/kesejahteraan Pegawai. 9) Prajabatan.

Kinerja aparatur sebagai penggerak organisasi publik merupakan elemen pokok pencapaian visi dan misi instansi pemerintah. Melalui pengukuran kinerja aparatur, keberhasilan suatu instansi pemerintah akan lebih dilihat dari kemampuan instansi tersebur berdasarkan sumber daya yang dikelolanya sesuai dengan rencana yang telah disusun. Kinerja adalah sesuatu yang dicapai atau prestasi yang diperlihatkan atau kemampuan bekerja, dengan kata lain bahwa kinerja dapat diartikan sebagai prestasi kerja menurut Simamora dalam Endang (2016:6).

Dalam manajemen sumber daya manusia banyak faktor yang mempengaruhi kinerja pegawai di antaranya menurut Gibson (2013:31) adalah motivasi kerja, kompetensi, komitmen, disiplin kerja, budaya organisasi, lingkungan kerja, gaya kepemimpinan dan sebagainya. Pada penelitian ini penulis hanya akan membahas faktor yang mempengaruhi kinerja pegawai adalah gaya pepemimpinan, motivasi kerja dan disiplin kerja.

Hasibuan (2016:170) menyatakan bahwa gaya kepemimpinan adalah cara seorang pemimpin mempengaruhi perilaku bawahan yang bertujuan untuk mendorong gairah kerja, kepuasan kerja dan produktivitas karyawan yang tinggi, agar dapat mencapai tujuan organisasi yang maksimal.

Motivasi kerja merupakan suatu hal yang penting yang sering disinggung oleh pimpinan organisasi baik secara terbuka maupun secara terselubung. Hal ini membuktikan pentingnya masalah motivasi tersebut dalam masalah kepemimpinan (Hartono 2014:78). Motivasi kerja merupakan suatu keinginan untuk berusaha sekuat-kuatnya mencapai tujuan organisasi, dipengaruhi oleh kemampuan untuk memuaskan beberapa kebutuhan individual. Motivasi secara umum berhubungan dengan segala usaha untuk mencapai tujuan, sedangkan tujuan organisasi dapat merefleksikan kepentingan tunggal yang berhubungan dengan perilaku sehubungan pekerjaan (Robbins 2012:45).

Menurut Rivai (2013:225) disiplin kerja adalah suatu alat yang dipergunakan para manajer untuk berkomunikasi dengan karyawan agar mereka bersedia untuk mengubah suatu perilaku serta sebagai suatu upaya untuk meningkatkan kesadaran dan kesedian seorang dalam memenuhi segala peraturan perusahaan. Hasibuan (2016:144) menyatakan disiplin kerja adalah kesadaran dan kerelaan seseorang dalam menaati semua peraturan perusahaan dan norma-norma sosial yang berlaku. 


\subsection{Objek Penelitian}

\section{METODOLOGI PENELITIAN}

Penelitian ini dilaksanakan pada Badan Kepegawaian dan Pengembangan Sumber Daya Manusia Kabupaten Kerinci. Alasan memilih lokasi ini adalah, peneliti terlibat langsung sebagai salah seorang pegawai. Objek yang akan diteliti adalah pengaruh gaya kepemimpinan, motivasi kerja dan disiplin kerja terhadap kinerja pegawai. Hasil penelitian yang diperoleh dapat dimanfaatkan sebagai gambaran informasi dalam upaya menentukan kebijakan peningkatan kinerja pegawai melalui gaya kepemimpinan, motivasi kerja dan disiplin kerja.

\subsection{Variabel Operasional}

Pada penelitian ini penulis menggunakan dua variabel yaitu:

- Variabel independen (bebas)

Variabel bebas adalah merupakan variabel yang mempengaruhi atau yang menjadi sebab perubahannya atau timbulnya variabel dependen atau terikat. Dalam penelitian ini yang menjadi variabel bebas (independent variable) adalah Gaya Kepemimpinan $\left(\mathrm{X}_{1}\right)$, Motivasi Kerja $\left(\mathrm{X}_{2}\right)$, Disiplin Kerja $\left(\mathrm{X}_{3}\right)$.

- Variabel dependen (terikat)

Variabel terikat merupakan variabel yang dipengaruhi atau yang menjadi akibat, karena adanya variabel bebas. Dalam penelitian ini yang menjadi variabel terikat (dependent variable) adalah Kinerja Pegawai (Y).

\subsection{Populasi dan Sampel}

Populasi adalah keseluruhan objek penelitian yang terdiri dari manusia, benda, hewan, tumbuhan, gejala-gejala, nilai tes atau peristiwa sebagai sumber data yang memiliki karakteristik tertentu dalam penelitian (Masngudi 2012:34). Di sisi lain Sugiyono (2012:46) berpendapat bahwa populasi adalah wilayah generalisasi yang terdiri dari objek atau subjek yang menjadi kuantitas dan karakteristik tertentu yang ditetapkan oleh peneliti untuk dipelajari dan kemudian ditarik kesimpulan.

Memahami kedua pendapat diatas, maka populasi penelitian ini adalah semua pegawai Badan Kepegawaian dan Pengembangan Sumber Daya Manusia Daerah Kabupaten Kerinci yang berjumlah 95 orang.

Merujuk pada pendapat Masngudi (2012:40) "Jika populasi penelitian kurang dari 100, lebih baik semua populasinya dijadikan sampel, selanjutnya jika populasinya lebih dari 100 maka sampelnya minimal 10-25\%".

Berdasarkan rujukan di atas, karena populasi kurang dari 100 orang, maka sampel penelitian ini adalah semua dari jumlah populasi yang ada yakni sebanyak 95 orang.

\subsection{Analisis Regresi Linier Berganda}

Menurut Sugiyono (2012:277) analisis ini untuk meramalkan bagaimana keadaan (naik turunnya) variabel dependen (kriterium), bila dua atau lebih variabel independen sebagai faktor prediktor dimanipulasi (dinaik turunkan nilainya). Jadi, analisis regresi berganda dilakukan bila jumlah variabel independentnya minimal 2. Persamaan regresi berganda sebagai berikut:

Keterangan :

$$
\mathbf{Y}=\mathbf{a}+\mathbf{b}_{1} \mathbf{X}_{1}+\mathbf{b}_{2} \mathbf{X}_{2}+\mathbf{b}_{3} \mathbf{X}_{3}+e
$$




$$
\begin{array}{ll}
\mathrm{Y} & =\text { Kinerja pegawai } \\
\mathrm{a} & =\text { Konstanta } \\
\mathrm{b} & =\text { Koefisien regresi } \\
\mathrm{X}_{1} & =\text { Gaya kepemimpinan } \\
\mathrm{X}_{2} & =\text { Motivasi kerja } \\
\mathrm{X}_{3} & =\text { Disiplin kerja } \\
\mathrm{e} & =\text { error }
\end{array}
$$

\section{Uji Parsial (Uji-t)}

Uji t pada dasarnya menunjukan seberapa jauh pengaruh satu variabel secara individual dalam menerangkan variasi variabel terikat. Pengujian melalui uji $\mathrm{t}$ adalah dengan membandingkan $\mathrm{t}$-hitung dengan $\mathrm{t}$-tabel pada derajat signifikasi $95 \%(\alpha=0,05)$ dengan pengujian dua sisi. Untuk menguji ini digunakan statistik t dengan rumus Algifari (2011:59).

\section{Uji Simultan (Uji-F)}

Uji F yaitu suatu uji untuk mengetahui pengaruh variabel bebas, yaitu Gaya Kepemimpinan $\left(\mathrm{X}_{1}\right)$, Motivasi Kerja $\left(\mathrm{X}_{2}\right)$, dan Disiplin Kerja $\left(\mathrm{X}_{3}\right)$ secara parsial atau individual terhadap variabel terikat yaitu Kinerja Pegawai (Y). Untuk mengetahui apakah variabel bebas secara bersama sama berpengaruh signifikan terhadap variabel terikat digunakan rumus Prayitno (2012:31).

\section{Uji Koefisien Determinasi (R-Square/ $\mathbf{R}^{2}$ )}

Koefisien determinasi digunakan untuk menjelaskan proporsi variabel terikat yang mampu dijelaskan oleh variabel- variabel bebasnya. Nilai koefisien determinasi adalah $0<\mathrm{R}^{2}<1$. Nilai $\mathrm{R}^{2}$ yang kecil berarti kemampuan variabel bebas yaitu Gaya Kepemimpinan $\left(\mathrm{X}_{1}\right)$, Motivasi Kerja $\left(\mathrm{X}_{2}\right)$, dan Disiplin Kerja $\left(\mathrm{X}_{3}\right)$, dalam menjalankan variabel terikat yaitu Kinerja Pegawai $(\mathrm{Y})$ sangat terbatas. Nilai yang mendekati satu berarti variabel bebas yaitu Gaya Kepemimpinan $\left(\mathrm{X}_{1}\right)$, Motivasi Kerja $\left(\mathrm{X}_{2}\right)$, Disiplin Kerja $\left(\mathrm{X}_{3}\right)$ dapat memberikan hampir semua informasi yang dibutuhkan untuk memprediksi semua variabel terikat yaitu Kinerja Pegawai (Y) Priyatno (2012:89).

\section{HASIL DAN PEMBAHASAN}

Berdasarkan sampel yang telah ditentukan diatas maka diperoleh responden sebanyak 95 orang. Dimana 95 responden tersebut peneliti ambil dari keseluruhan populasi yang ada pada BKPSDMD Kabupaten Kerinci. Data yang disebarkan sebanyak 95 kuesioner dan berhasil dikumpulkan kembali kemudian diolah semuanya.

\section{Uji Normalitas}

Uji normalitas bertujuan untuk menguji apakah dalam sebuah model regresi, variabel dependent dan independent mempunyai distribusi normal atau tidak. Model regresi yang baik adalah distribusi data normal atau mendekati normal, deteksi normalitas dengan melihat penyebaran data (titik) pada sumbu diagonal dari grafik. Cara yang bisa ditempuh untuk menguji kenormalan data adalah dengan menggunakan grafik normal P-P Plot dengan cara melihat penyebaran datanya. Jika pada grafik tersebut penyebaran datanya mengikuti pola garis lurus, maka datanya nornal. Jika pada tabel test of normality dengan menggunakan kolmogorov-smirnov 
nilai sig > 0,05, maka data berdistribusi normal. Hasil uji normalitas dalam penelitian ini adalah sebagai berikut:

Tabel 4.1 Uji Normalitas

\begin{tabular}{|c|c|c|}
\hline & & $\begin{array}{c}\text { Unstandardi } \\
\text { zed } \\
\text { Residual }\end{array}$ \\
\hline $\mathrm{N}$ & & 95 \\
\hline Normal & Mean & ,0000000 \\
\hline $\begin{array}{l}\text { Parameters } \\
\mathrm{b}\end{array}$ & $\begin{array}{l}\text { Std. } \\
\text { Deviation }\end{array}$ & 3,06866106 \\
\hline Most & Absolute & ,060 \\
\hline Extreme & Positive & 060 \\
\hline Differences & Negative &,- 051 \\
\hline \multicolumn{2}{|c|}{ Test Statistic } &, 582 \\
\hline \multicolumn{2}{|c|}{ Asymp. Sig. (2-tailed) } & ,887 \\
\hline
\end{tabular}

Sumber : Data diolah peneliti, 2020

Tabel 4.1 di atas terlihat uji normalitas menunjukkan Asymp.Sig (2-tailed) lebih besar dari 0,05 yaitu 0,887. Ini mengindentifikasikan bahwa data terdistribusi normal sehinga layak dipakai untuk analisis regresi berganda.

\section{Uji Multikolinearitas}

Uji ini bertujuan untuk menguji apakah model regresi ditemukan adanya korelasi antar variabel bebas (independent). Model regresi yang baik, seharusnya tidak terjadi korelasi diantara variabel independen. Jika variabel independen saling berkorelasi, maka variabel-variabel ini tidak orthogonal. Untuk mendeteksi adanya multikolinieritas, dapat dilihat value inflation factor (VIF). Apabila nilai VIF $>10$, terjadi multikolinieritas. Sebaliknya, jika VIF $<10$, tidak terjadi multikolinieritas. Maka hasilnya dapat dilihat dari tabel 4.2 di bawah ini:

\section{Tabel 4.2 Hasil Uji Multikolinearitas}

\begin{tabular}{|c|c|c|c|}
\hline \multicolumn{4}{|c|}{$\begin{array}{l}\text { Collinearity } \\
\text { Statistics } \\
\text { Toleran }\end{array}$} \\
\hline & Model & ce & VIF \\
\hline 1 & $\begin{array}{l}\text { (Consta } \\
\mathrm{nt)}\end{array}$ & & \\
\hline & GK & ,646 & 1,547 \\
\hline & MK & ,881 & 1,134 \\
\hline & DK &, 592 & 1,690 \\
\hline
\end{tabular}

Dari tabel 4.2 di atas dapat diketahui bahwa semua nilai tolerance $>0,10$ dan hasil perhitungan nilai VIF $<10$ ini berarti tidak terjadi gejala multikolinieritas antar variabel independen. Dengan demikian dapat disimpulkan bahwa persamaan regresi yang digunakan sebagai prediksi dalam penelitian ini bebas dari asumsi klasik. 


\section{Uji Heteroskedastisitas}

Pengujian ini digunakan untuk melihat apakah variabel penggangu mempunyai varian yang sama atau tidak. Heteroskedastisitas mempunyai suatu keadaan bahwa varian dari residual suatu pengamatan yang lain berbeda. Salah satu metode yang digunakan untuk menguji ada tidaknya heteroskedastisitas akan mengakibatkan penaksiran koefisien-koefisien regresi menjadi tidak efisien. Hasil penaksiran akan menjadi kurang dari semestinya.

\section{Gambar 4.3 Hasil Uji Heteroskedastisitas}

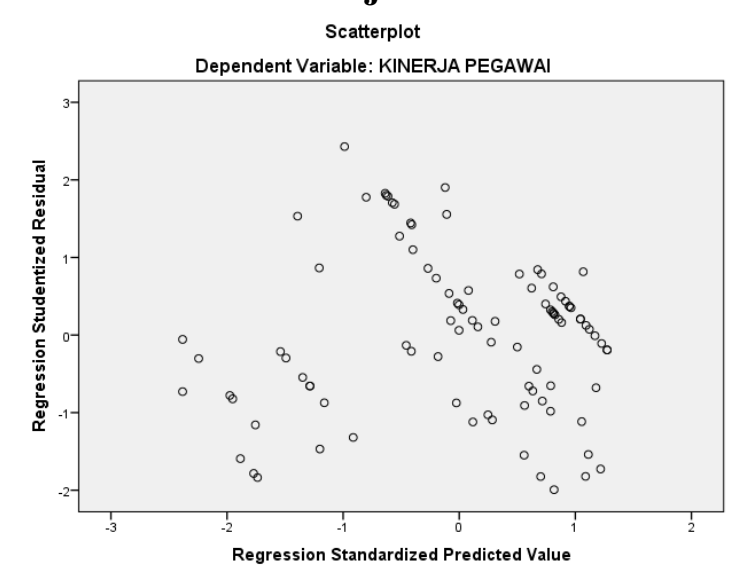

Sumber : Data diolah peneliti, 2020

Dari grafik di atas dapat diketahui bahwa tidak terjadi heteroskedastisitas pada model regresi sebab tidak ada pola yang jelas serta titik-titik menyebar di atas dan di bawah angka 0 pada sumbu Y. Sehingga dapat dikatakan uji heteroskedastisitas terpenuhi.

\section{Analisis Regresi Linier Berganda}

Analisis regresi digunakan untuk melihat pengaruh variabel independen : gaya kepemimpinan, motivasi kerja, dan disiplin kerja secara simultan terhadap variable dependen : kinerja pegawai dengan asumsi variabel independen lain dianggap konstan. Adapun bentuk regresinya adalah sebagai berikut:

Berdasarkan perhitungan diperoleh nilai koefisien regresi gaya kepemimpinan $\left(\mathrm{X}_{1}\right)$ sebesar 0,432 , nilai koefisien regresi motivasi kerja $\left(\mathrm{X}_{2}\right)$ sebesar 0,127, nilai koefisien regresi disiplin kerja $\left(X_{3}\right)$ sebesar 0,198. Berdasarkan angka tersebut maka dapat disusun persamaan garis regresi sebagai berikut :

\section{Uji Parsial (Uji-t)}

$$
Y=8,710+0,432 X_{1}+0,127 X_{2}+0,198 X_{3}+e
$$

Uji t dimaksudkan untuk mengetahui seberapa jauh pengaruh satu variabel independen (gaya kepemimpinan, motivasi kerja, dan disiplin kerja) Secara individual dalam menerangkan variabel dependen (kinerja pegawai). Berdasarkan tabel 4.3 diatas maka dapat ditarik kesimpulan bahwa :

a. Pengaruh Gaya Kepemimpinan (X1) terhadap Kinerja Pegawai (Y)

Dari tabel di atas terlihat t-hitung 9,522 dan t-tabel 1,661, di mana t-hitung lebih besar dari t-tabel $(9,522>1,661)$ atau tingkat signifikan lebih kecil dari alpha $(0,000<0,05)$. 
$\mathrm{H}_{\mathrm{o}}$ : Tidak terdapat pengaruh signifikan antara variabel gaya kepemimpinan terhadap kinerja pegawai.

$\mathrm{H}_{\mathrm{a}}$ : Terdapat pengaruh signifikan antara variabel gaya kepemimpinan terhadap kinerja pegawai.

Dari hasil perbandingan terlihat t-hitung dan t-tabel, maka dapat di ambil kesimpulan bahwa secara parsial ada pengaruh yang signifikan gaya kepemimpinan terhadap kinerja pegawai. Dengan demikian H0 ditolak H1 diterima.

b. Pengaruh Motivasi Kerja (X2) terhadap Kinerja Pegawai (Y)

Dari tabel di atas terlihat t-hitung 2,798 dan t-tabel 1,661, dimana t-hitung lebih besar dari t-tabel $(2,798>1,661)$ atau tingkat signifikan lebih kecil dari alpha $(0,006<0,05)$.

$\mathrm{H}_{\mathrm{o}}$ : Tidak terdapat pengaruh signifikan antara variabel motivasi kerja terhadap kinerja pegawai.

$\mathrm{H}_{\mathrm{a}}$ : Terdapat pengaruh signifikan antara variabel motivasi kerja terhadap kinerja pegawai.

Dari hasil perbandingan terlihat t-hitung dan t-tabel, maka dapat di ambil kesimpulan bahwa secara parsial ada pengaruh yang signifikan antara motivasi kerja dengan kinerja pegawai. Dengan demikian H0 ditolak H2 diterima.

c. Pengaruh Disiplin Kerja (X3) terhadap Kinerja Pegawai (Y)

Dari tabel di atas terlihat t-hitung 4,455 dan t-tabel 1,661, dimana t-hitung lebih besar dari t-tabel $(4,455>1,661)$ atau tingkat signifikan lebih kecil dari alpha $(0,000<0,05)$.

$\mathrm{H}_{\mathrm{o}}$ : Tidak terdapat pengaruh signifikan antara variabel disiplin kerja terhadap kinerja pegawai.

$\mathrm{H}_{\mathrm{a}}$ : Terdapat pengaruh signifikan antara variabel disiplin kerja terhadap kinerja pegawai.

Dari hasil perbandingan terlihat t-hitung dan t-tabel, maka dapat di ambil kesimpulan bahwa secara parsial ada pengaruh yang signifikan antara disiplin kerja dengan kinerja pegawai. Dengan demikian H0 ditolak H3 diterima.

\section{Uji Simultan (Uji-F)}

Uji F digunakan untuk menguji ada tidaknya pengaruh variabel-variabel independen terhadap variabel dependen secara simultan (bersama-sama). Berdasarkan hasil pengujian diperoleh ringkasan hasil seperti yang terlihat pada tabel di bawah ini : 


\begin{tabular}{lrrrrr}
\hline \multicolumn{3}{c}{ Sum of } & & & \\
\multicolumn{1}{c}{ Square } & & Mean \\
Model & \multicolumn{1}{c}{ s } & df & Square & \multicolumn{1}{c}{ F } & Sig. \\
\hline 1 Regressi & 2650,7 & 3 & 883,59 & 90,83 &, 000 \\
on & 90 & & 7 & 8 & b \\
Residual & 885,16 & 91 & 9,727 & & \\
& 8 & & & & \\
Total & 3535,9 & 94 & & & \\
& 58 & & & & \\
&
\end{tabular}

Sumber : Data diolah peneliti, 2020

Dari tabel 4.4 di atas, diketahui bahwa pengujian pengaruh variabel bebas secara bersama-sama terhadap variabel terikatnya dilakukan dengan menggunakan uji F. Hasil perhitungan statistik menunjukkan nilai F-hitung lebih besar dari Ftabel $(90,838>2,70)$, dengan signifikansi sebesar $0,000<0,05$. Hal ini berarti bahwa secara bersama-sama dari gaya kepemimpinan, motivasi kerja dan disiplin kerja berpengaruh positif terhadap kinerja pegawai.

\section{Uji Koefisien Determinasi (R-Square)}

Koefisien determinasi R (square) digunakan untuk mengetahui seberapa besar kontribusi variabel-variabel bebas dalam menjelaskan variabel terikat. Berdasarkan hasil pengujian diperoleh ringkasan hasil seperti yang terlihat pada tabel di bawah ini :

\section{Tabel 4.5 Hasil Uji Koefisien Determinasi}

\section{Durbi}

n-

Adjuste Wats

Mod $\mathrm{R} \quad \mathrm{d} R$ on

\begin{tabular}{lrrrr} 
el & $\mathrm{R}$ & Square & Square & \\
\hline 1 &, $866^{\mathrm{a}}$ &, 750 &, 741 & 3,119 \\
\hline
\end{tabular}

Sumber : Data diolah peneliti, 2020

Dari tabel di atas diketahui angka Adjusted $R$ Square sebesar 0,741 atau $74,1 \%$, hal ini menunjukkan bahwa persentase sumbangan variabel independen gaya kepemimpinan (X1), motivasi kerja (X2) dan disiplin kerja (X3) terhadap variabel dependen kinerja pegawai (Y) sebesar 0,741 atau 74,1\%. Sedangkan sisanya sebesar $25,9 \%$ dipengaruhi oleh variabel lain di luar penelitian yaitu, komitmen pegawai, budaya organisai, pelatihan, dan lingkungan kerja.

\section{Pembahasan}

1. Pengaruh Gaya Kepemimpinan terhadap Kinerja Pegawai

Hasil yang diperoleh terdapat pengaruh antara gaya kepemimpinan terhadap kinerja pegawai maka diperoleh nilai koefisien yaitu 0,432 yang berarti gaya kepemimpinan berpengaruh terhadap kinerja pegawai, sedangkan nilai pvalue $=$ $0,000<0,05$ berarti ada pengaruh yang signifikan antara gaya kepemimpinan dengan kinerja pegawai. Hal ini sejalan dengan penbelitian yang dilakukan oleh (Endang Sukarjati, dkk, 2016) yang menunjukkan bahwa gaya kepemimpinan dapat mempengaruhi kinerja pegawai. Dengan demikian ada pengaruh yang positif dan signifikan antara gaya kepemimpinan dengan kinerja pegawai. 
Dengan demikian terbukti bahwa gaya kepemimpinan berpengaruh positif dan signifikan terhadap kinerja pegawai. Dari hasil tersebut dapat diberikan rekomendasi, bahwa kinerja pegawai akan meningkat jika seorang pemimpin mempunyai gaya kepemimpinan yang memiliki :

1. Kemapuan mengambil keputusan

2. Kemampuan memotivasi

3. Kemampuan komunikasi

4. Kemampuan mengendalikan bawahan

5. Tanggung jawab

6. Kemampuan mengendalikan emosi

2. Pengaruh Motivasi Kerja Terhadap Kinerja Pegawai

Hasil yang diperoleh terdapat pengaruh antara motivasi kerja dengan kinerja pegawai maka diperoleh nilai koefisien yaitu 0,127 yang berarti motivasi kerja berpengaruh positif terhadap kinerja pegawai, sedangkan nilai pvalue $=0,006<$ 0,05 berarti ada pengaruh yang signifikan antara motivasi kerja dengan kinerja pegawai. Hal ini sejalan dengan penelitian yang dilakukan oleh (Deden Santa Winata Kusumah, dkk, 2018) yang menunjukkan bahwa motivasi kerja berpengaruh terhadap kinerja pegawai. Dengan demikian ada pengaruh yang positif dan signifikan antara motivasi kerja dengan kinerja pegawai.

Dengan demikian terbukti bahwa motivasi kerja berpengaruh signifikan terhadap kinerja pegawai. Dari hasil tersebut dapat diberikan rekomendasi, bahwa kinerja pegawai akan meningkat jika motivasi kerja yang dimiliki pegawai terus meningkat dengan adanya:

1. Kebutuhan dalam berprestasi

2. Kebutuhan berafiliasi

3. Kebutuhan akan kekuasaan

3. Pengaruh Disiplin Kerja Terhadap Kinerja Pegawai.

Hasil yang diperoleh terdapat pengaruh antara disiplin kerja dengan kinerja pegawai maka diperoleh nilai koefisien yaitu 0,198 yang berarti disiplin kerja berpengaruh positif terhadap kinerja pegawai, sedangkan nilai pvalue $=0,000<$ 0,05 berarti ada pengaruh yang signifikan antara disiplin kerja dengan kinerja pegawai. Hal ini sejalan dengan penbelitian yang dilakukan oleh (Rizal Febrinal, 2012) yang menunjukkan bahwa disiplin kerja memiliki pengaruh yang signifikan terhadap kinerja pegawai.

Dengan demikian terbukti bahwa disiplin kerja berpengaruh signifikan terhadap kinerja pegawai. Dari hasil tersebut dapat diberikan rekomendasi, bahwa kinerja pegawai akan meningkat jika disiplin kerja pegawai meningkat dengan memperhatikan hal-hal seperti :

1. Taat terhadap aturan waktu

2. Taat terhadap peraturan perusahaan

3. Taat terhadap aturan perilaku dalam pekerjaan

4. Taat terhadap peraturan lainnya di perusahaan

\section{KESIMPULAN}


Hasil penelitian ini menunjukkan bahwa gaya kepemimpinan berpengaruh dan signifikan terhadap kinerja pegawai, motivasi kerja berpengaruh dan signifikan terhadap kinerja pegawai, disiplin kerja berpengaruh dan signifikan terhadap kinerja pegawai, gaya kepemimpinan, motivasi kerja dan disiplin kerja secara bersama-sama berpengaruh dan signifikan terhadap kinerja pegawai BKPSDMD Kabupaten Kerinci.

\section{DAFTAR PUSTAKA}

Abdul Razak, et. al .2018. Effect of Leadership Style, Motivation and Work Discipline on Employee Performance in PT. ABC Makassar. Econ Journals IRMM, ISSN : 2146-4405. 2018, 8(6), 67-71.

Algifari. 2011. Analisis regresi untuk bisnis dan ekonomi. Edisi 3. Yogyakarta : ANDI.

Andi Ratna Sari Dewi. 2017. Pengaruh Gaya Kepemimpinan, Budaya Organisasi dan Komitmen Organisasi Terhadap Kinerja Pegawai Dinas Pertanian Kabupaten Mamuju. Jurnal JBMI Vol. 14 No. 2 Oktober 2016.

Basna, Frengky. 2016. Analisis Gaya Kepemimpinan, Kepuasan Kerja, Komitmen Organisasi dan Kompetensi terhadap Kinerja Pegawai. Jurnal Riset Bisnis dan Manajemen, Vol 4 , No 3, 2016: 319-334.

Bernardin, H. John And Russell, Joyce E. A. 2013. Human Resource Management. New York : McGraw-Hill Inc.

Dinie Anisa Triastuti. 2018. Pengaruh Lingkungan Kerja, Kompetensi Dan Iklim Organisasi Terhadap Kinerja Pegawai Pada Bank BJB Cabang Tasikmalaya. Journal Of Management Review ISSN-P : 2580-4138 Vol 2 No. 1.

Dharma, A. 2014. Managemen Prestasi Kerja. Jakarta : Rajawali Press.

Endang Sukarjati, dkk. 2016. Pengaruh Kepemimpinan, Pengembangan Sumber Daya Manusia Dan Kepuasan Kerja Terhadap Kinerja. Journal Of Management Vol. 02 No.02, Maret 2016.

Ernest J. McCormick. 2011. Indutrial Psycology. New York : Prentice Hall, Inc.

Fillmore, H Stanford. 2008. Manajemen Sumber Daya Manusia, Edisi Revisi, Yogyakarta : Erlangga

Ghozali, Imam. 2011. Aplikasi Analisis Multivariate Dengan Program SPSS. Semarang: Badan Penerbit Universitas Diponegoro.

Gibson, James L. 2013. Organizations (Behavior, Structure, Processes). Twelfth Edition. New York : McGraw Hill.

Hasibuan, Malayu S.P. 2016. Manajemen Sumber Daya Manusia, Edisi revisi. Jakarta : PT. Bumi Aksara.

Handoko, T.H. 2016. Manajemen Personalia dan Sumber Daya Manusia. Yogyakarta: BPFE Press.

Hartono, J. 2014. Metodologi Penelitian Bisnis : Salah Kaprah dan PengalamanPengalaman (Edisi 6). Yogyakarta : BPFE

Heri Saputra. 2012. Analisis Pengaruh pelatihan, locus of control dan disiplin kerja terhadap kinerja Karyawan PT BPR Dharma di Kota Solo. Jurnal Manajemen dan Bisnis Vol.14 No. 1 Februari 2012. 
Hemhill \& Coons, 2010, Kepemimpinan dalam Pengembangan Organisasi, Jurnal Lintasan Ekonomi Fakultas Ekonomi Universitas Brawijaya Malang, Vol.18 No.1.

http://kmpk.ugm.ac.id

Kartono, Kartini. 2010. Pemimpin dan Kepemimpinan. Jakarta : PT. Raja Grafindo Persada.

Kusumah, Deden Santa Winata, dkk. 2018. Pengaruh Kepemimpinan, Motivasi Kerja dan Kompensasi Terhadap Kinerja (Studi Pada Pegawai Kantor Imigrasi Kelas II Karawang). Jurnal Bisnis dan Manajemen Eksekutif Vol. 1 No. 2, Universitas Singaperbangsa Karawang. 5 Mei 2018.

Luthans, Fred. 2015. Perilaku Organisasi, Edisi Sepuluh. Yogyakarta : ANDI. Mangkunegara, Anwar Prabu. 2017. Sumber Daya Manusia Perusahaan. Remaja Rosdakarya : Bandung.

Masngudi. 2012. Metodologi Penelitian Untuk Ekonomi \& Bisinis, Jakarta: Trianandra University Press.

Moeheriono. 2012. Pengukuran Kinerja Berbasis Kompetensi. Jakarta : Raja Grafindo Persada.

Nawawi, Hadari. 2011. Kepemimpinan Mengektifkan Organisasi. Yogyakarta: Gajah Mada University Press.

Nitisemito, Alex S. 2015. Manajemen Personalia. Jakarta: Ghalia Indonesia

Priyatno, Duwi. 2012. Cara Kilat Belajar Analisis Data dengan SPSS 20. Edisi Kesatu. Yogyakarta: ANDI.

Richard Christian Turang, et. al. 2015. Influence Of Leadership Style, Motivation, and Work Discipline On Employee Performance In PT Dayana Cipta. JBIE Vol.15 No.4 Tahun 2015.

Rizal Febrinal. 2012. Analisis Dampak Disiplin Kerja, Komitmen dan Gaya Kepemimpinan terhadap Kinerja Pegawai Badan Lingkungan Hidup, Kebersihan dan Pertamanan Kabupaten Lampung Barat. Jurnal Manajemen, Strategi Bisnis, Vol. 06, No. 02 Agustus 2012.

Robbins, Stephen P \& Judge, Timothy A. 2014. Perilaku Organisasi. Penerjemah, Diana Angelica. Jakarta : Salemba Empat.

Robbins, Stephen P. \& Coulter, Mary. 2012. Management. New Jersey: Pearson Education, Inc.

Rivai, Veithzal. 2013. Manajemen Sumber Daya Manusia untuk Perusahaan, Edisi ke 6. Depok : PT. Raja Grafindo Persada.

Siagian P, Sondang. 2014. Manajemen Sumber Daya Manusia. Jakarta:

Bumi Aksara

Sugiyono. 2012. Metode Penelitian. Bandung : CV. Alfabeta.

Sutrisno, H. Edy. 2011. Manajemen Sumber Daya Manusia. Jakarta: Kencana

Sunyoto, Danang. 2013. Manajemen Sumber Daya Manusia. Jakarta: PT Buku Seru.

Tampi, Bryan Johannes. 2014. Pengaruh Gaya Kepemimpinan dan Motivasi Terrhadap Kinerja Karyawan pada PT. Bank Negara Indonesia, Tbk (Regional Sales Manado). Journal “Acta Diurna” Volume III. No.4. Tahun 2014

Thoha, Miftah, 2012. Perilaku Organisasi - konsep dasar dan aplikasinya. Jakarta : Penerbit Rajawali. 
Timpe, A. Dale. 2012. Kepemimpinan. Penerjemah, Susanto Budi dharma. Jakarta: Elex Media Komputindo.

Tulus, Agus. 2016. Manajemen Sumber Daya Manusia. Jakarta: Gramedia.

Umar, Husein. 2013. Metode Penelitian Untuk Skripsi dan Tesis. Jakarta : Rajawali.

Teinike, W. Yulvera. 2011. Analisis Kinerja Pegawai Berdasarkan Gaya Kepemimpinan, Kompetensi Dan Motivasi Kerja Pada Dinas Kebudayaan Dan Pariwisata Kota Padang. Jurnal Manajemen Vol. 31 No.1, Juni 2011 : 71-80.

Wirawan. 2014. Sumber Daya Manusia. Jakarta : Selemba Empat.

Windi Dwi Aprillianto. 2019. Pengaruh Peran Pemimpin dan Komitmen Afektif Terhadap Kepuasan Kerja Dan Kinerja Pegawai Negeri Sipil Bagian Umum Dan Kepegawaian Sekretariat Kabupaten Kutai Timur. Jurnal Pemikiran Ilmiah dan Pendidikan Administrasi Perkantoran, Vol. 4, No. 1, 2019

Yukl, Gary, 2010. Kepemimpinan dalam Organisasi, Edisi Kelima. Penerjemah, Budi Supriyanto. Jakarta: PT. Indeks.

Zainun, Buchari. 2015. Manajemen dan Motivasi, Edisi Revisi. Jakarta: Balai Aksara. 